Article

\title{
Steel Wool for Water Treatment: Intrinsic Reactivity and Defluoridation Efficiency
}

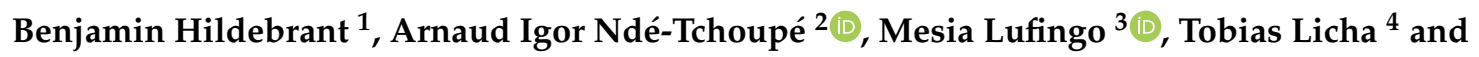 \\ Chicgoua Noubactep $1,5, *$ (D) \\ 1 Angewandte Geologie, Universität Göttingen, Goldschmidtstraße 3, D-37077 Göttingen, Germany; \\ hildebrantb@gmail.com \\ 2 Department of Chemistry, Faculty of Sciences, University of Douala, Douala B.P. 24157, Cameroon; \\ ndetchoupe@gmail.com \\ 3 Department of Water and Environmental Science and Engineering, Nelson Mandela African Institution of \\ Science and Technology, Arusha P.O. Box 447, Tanzania; lufingom@nm-aist.ac.tz \\ 4 Institut für Geologie, Mineralogie und Geophysik Fakultät für Geowissenschaften Ruhr-Universität Bochum \\ Universitätsstraße, 15044801 Bochum, Germany; tobias.licha@rub.de \\ 5 School of Earth Science and Engineering, Hohai University, Fo Cheng Xi Road 8, Nanjing 211100, China \\ * Correspondence: cnoubac@gwdg.de
}

Received: 31 December 2019; Accepted: 24 February 2020; Published: 26 February 2020

check for updates

\begin{abstract}
Studies were undertaken to characterize the intrinsic reactivity of $\mathrm{Fe}^{0}$-bearing steel wool $\left(\mathrm{Fe}^{0} \mathrm{SW}\right)$ materials using the ethylenediaminetetraacetate method (EDTA test). A 2 mM Na 2 -EDTA solution was used in batch and column leaching experiments. A total of $15 \mathrm{Fe}^{0} \mathrm{SW}$ specimens and one granular iron (GI) were tested in batch experiments. Column experiments were performed with four $\mathrm{Fe}^{0} \mathrm{SW}$ of the same grade but from various suppliers and the GI. The conventional EDTA test $(0.100 \mathrm{~g}$ $\mathrm{Fe}^{0}, 50 \mathrm{~mL}$ EDTA, $96 \mathrm{~h}$ ) protocol was modified in two manners: (i) Decreasing the experimental duration (down to $24 \mathrm{~h}$ ) and (ii) decreasing the $\mathrm{Fe}^{0}$ mass (down to $0.01 \mathrm{~g}$ ). Column leaching studies involved glass columns filled to $1 / 4$ with sand, on top of which $0.50 \mathrm{~g}$ of $\mathrm{Fe}^{0}$ was placed. Columns were daily gravity fed with EDTA and effluent analyzed for Fe concentration. Selected reactive $\mathrm{Fe}^{0} \mathrm{SW}$ specimens were additionally investigated for discoloration efficiency of methylene blue (MB) in shaken batch experiments $(75 \mathrm{rpm})$ for two and eight weeks. The last series of experiments tested six selected $\mathrm{Fe}^{0} \mathrm{SW}$ for water defluoridation in $\mathrm{Fe}^{0}$ /sand columns. Results showed that (i) the modifications of the conventional EDTA test enabled a better characterization of $\mathrm{Fe}^{0} \mathrm{SW}$; (ii) after 53 leaching events the $\mathrm{Fe}^{0} \mathrm{SW}$ showing the best $\mathrm{k}_{\mathrm{EDTA}}$ value released the lowest amount of iron; (iii) all $\mathrm{Fe}^{0}$ specimens were efficient at discoloring cationic $\mathrm{MB}$ after eight weeks; (iv) limited water defluoridation by all six $\mathrm{Fe}^{0} \mathrm{SW}$ was documented. Fluoride removal in the column systems appears to be a viable tool to characterize the $\mathrm{Fe}^{0}$ long-term corrosion kinetics. Further research should include correlation of the intrinsic reactivity of SW specimens with their efficiency at removing different contaminants in water.
\end{abstract}

Keywords: dye discoloration; ethylenediaminetetraacetic acid; intrinsic reactivity; water defluoridation; zero-valent iron

\section{Introduction}

The knowledge that metallic iron $\left(\mathrm{Fe}^{0}\right)$ is the parent of iron oxides and hydroxides ("rust", iron corrosion products or FeCPs) is well-established and has been used for water treatment for more than 170 years [1-7]. As a rule, small pieces of $\mathrm{Fe}^{0}$ (iron filings, iron shaving, scrap iron, steel wool) are brought in contact with polluted water in static [8], semi-dynamic [2], or dynamic [6] systems. A myriad of $\mathrm{Fe}^{0}$ materials have been manufactured or selected, tested, and used for water 
treatment both at small and large scales between 1850 and 1930 [1,9-11]. By the early 20th century, around World War I, steel wool (SW) has been mass-produced, and became an essential cleaning instrument in households. This mass-production makes SW probably the most widespread $\mathrm{Fe}^{0}$ materials worldwide [12-14]. In particular, each visually thin strand of SW is made of thousands of metal fibres that are very reactive $[15,16]$. The rapid kinetics of SW corrosion justifies its use in scholar practical demonstrations [17-20].

The first application of SW for safe drinking water provision is probably the one presented by Emmons in the 1950s-Emmons Process [21,22]. After the Emmons Process, $\mathrm{Fe}^{0} \mathrm{SW}$ and other forms of $\mathrm{Fe}^{0}$ materials were intermittently reported in water treatment worldwide [15,23-27]. In the western scientific literature, $\mathrm{Fe}^{0}$ was rediscovered in the 1980s [16,25,28]. For example, Tseng et al. [25] used SW to concentrate radioactive Cobalt in sea water samples; Erickson et al. [29-31] used SW to reinforce the phosphorus removal capacity of filtration systems; Albinsson et al. [26] and Del Cul and Bostick $[32,33]$ used SW to mitigate the migration of radionuclides from waste repositories; James et al. [34] used SW to reinforce the phosphorus removal capacity of peat based filtration systems. In general, testing SW for water treatment became common place, even though available results are to be regarded as independent reports [35]. From 1995 on, SW was tested for the removal of various contaminants including arsenic [36,37], chromium [38,39], nitrate [40,41], pathogens [42,43], and selenium [44]. However, SW is just used as a class of reactive material mostly without any reactivity characterization [35]. To the best of the author's knowledge, Hildebrant [45], Lufingo [14], and Ndé-Tchoupé [13] have presented the first attempts to systematically characterize the intrinsic reactivity of $\mathrm{Fe}^{0} \mathrm{SW}$.

The named authors basically used the ethylenediaminetetraacetate method (EDTA test) and the methylene blue discoloration method (MB test) $[13,14,45]$. Lufingo [14] additionally presented a novel test in which EDTA is replaced by 1,10-Phenanthroline (Phen test) [12]. The EDTA and the Phen tests are rooted on the evidence, that the initial $\mathrm{Fe}^{0}$ dissolution in aqueous solutions containing a complexing agent (EDTA or Phen) is a linear function of time and the slope of the line is characteristic for each $\mathrm{Fe}^{0}$ specimen. On the other hand, the MB test relies on the evidence that MB adsorption onto positively charged iron corrosion products (FeCPs) is not favorable [46-48]. Accordingly, the kinetics of MB discoloration by $\mathrm{Fe}^{0}$ materials is slow and can be better characterized [49]. When a $\mathrm{Fe}^{0} /$ sand system is characterized using the $\mathrm{MB}$ test, for a certain time frame, the more efficient system is the one depicting the lowest MB discoloration. This observation is justified by the fact that sand, which is an excellent adsorbent for cationic $\mathrm{MB}$ is progressively coated by positively charged FeCPs. Coated sand depicts a lower adsorptive affinity for MB than clean sand $[46,48]$. The merit of the three named tests (EDTA, $\mathrm{MB}$, and Phen) is that, similar to $\mathrm{H}_{2}$ evolution [50,51], they do characterize an intrinsic property of each $\mathrm{Fe}^{0}$ (intrinsic reactivity) and results are transferable to all systems, unlike characterization tools based on the $\mathrm{Fe}^{0}$ removal efficiency for individual contaminants [52-55].

A constant problem within the " $\mathrm{Fe}^{0}$ remediation" research community is that the terms "efficiency" and "reactivity" are mostly randomly interchanged [49,56-58]. In essence, reactivity is an intrinsic property of a material that cannot change. It can also not be quantified into which number. It can only be indirectly assessed, for example with the dissolution rate in EDTA or Phen solutions. The extent of $\mathrm{MB}$ discoloration by a given $\mathrm{Fe}^{0}$ mass under well-defined conditions can also be used to assess its intrinsic reactivity. In all the cases, unified standard protocols are needed. The Phen test is the current best candidate for such a protocol [12]. Efficiency, on the other hand, is the expression of the reactivity as influenced by operational or site-specific conditions (e.g., $\mathrm{pH}$ value, salinity) [57].

The present work is an attempt to correlate "efficiency" and "reactivity" of selected $\mathrm{Fe}^{0} \mathrm{SW}$ by using materials of known intrinsic reactivity (EDTA test) for MB discoloration and water defluoridation. Parallel batch and column experiments are performed and the results are comparatively discussed. 


\section{Material and Methods}

\subsection{Aqueous Solutions}

\subsubsection{EDTA}

The ethylenediaminetetraacetic acid (EDTA) solution used for the experiments was prepared by dissolving an analytical grade disodium salt of EDTA ( $\mathrm{Na}_{2}-$ EDTA from Merck-Darmstadt/Germany) in tap water and diluting to a concentration of $0.002 \mathrm{M}(2 \mathrm{mM})$. The tap water of the city of Göttingen has a very constant composition with low level of cations. For similar experiments in Cameroon or Tanzania our research group used deionized water.

\subsubsection{TISAB}

Total ionic strength adjustment buffer (TISAB) was used to regulate the ionic strength and $\mathrm{pH}$ of samples prior to determination of fluoride concentration with the ion selective electrode. The buffer solution was prepared by adding $1500 \mathrm{~mL}$ of tap water to a $2500 \mathrm{~mL}$ glass beaker, to which $114.0 \mathrm{~mL}$ of glacial acetic acid, $116.0 \mathrm{~g}$ of table salt $(\mathrm{NaCl})$, and $6.42 \mathrm{~g}$ of $\mathrm{Na}_{2}$-EDTA were added. The mixture was heated and stirred with a magnetic stir rod and then allowed to cool to room temperature. Additional tap water was then added until the total solution volume reached $2000 \mathrm{~mL}$, and the $\mathrm{pH}$ was adjusted by using a $5 \mathrm{M} \mathrm{NaOH}$ solution until a $\mathrm{pH}$ value of 5.3 was obtained. The TISAB solution was stored in clean polyethylene bottles.

\subsubsection{Methylene Blue $\left(\mathrm{C}_{16} \mathrm{H}_{18} \mathrm{CIN}_{3} \mathrm{~S}\right)$}

Analytical grade Methylene Blue was purchased from Acros Organics and used as received. The working solution had a concentration of $10.0 \mathrm{mg} / \mathrm{L}$. MB is a cationic dye that has a strong affinity for the surface of negatively charged solids [46,59]. MB has a maximum light absorption wavelength of $664.5 \mathrm{~nm}$ and a molecular mass of $319.85 \mathrm{~g} \mathrm{~mol}^{-1}$.

\subsubsection{Additional Solutions}

A standard iron solution (1000 $\left.\mathrm{mg} \mathrm{L}^{-1}\right)$ from Baker $\mathrm{JT}^{\circledR}$ was used to calibrate the spectrophotometer.

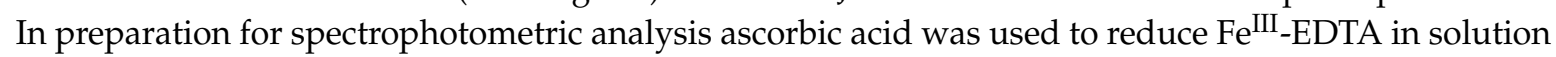
to Fe $\mathrm{FI}^{\mathrm{II}}$-EDTA. 1,10 orthophenanthroline (ACROS Organics) was used as reagent for Fe $\mathrm{F}^{\mathrm{II}}$ complexation prior to spectrophotometric determination. Other chemicals used in this study included L(+)-ascorbic acid, L-ascorbic acid sodium salt, and sodium acetate. All chemicals were of analytical grade.

\subsection{Solid Materials}

\subsubsection{Sand}

The sand used in all of the column experiments is commercially available for aviculture ("Aquarienkies" sand from Quarzverpackungwerek Rosnerski Königslutter/Germany). The grain sizes of used Aquarienkies sand ranged between 2.0 and $4.0 \mathrm{~mm}$ (average diameter). The sand was used without additional pretreatment or characterization. Sand was used because of its worldwide availability and its use as admixing agent in $\mathrm{Fe}^{0} / \mathrm{H}_{2} \mathrm{O}$ systems [60].

\subsubsection{Steel Wool $\left(\mathrm{Fe}^{0}\right)$}

A total of fifteen different types of steel wool were used in this work. Six varieties of SW were purchased at a local hardware store in Göttingen (Germany) and two steel wool varieties were purchased in Tengeru (Tanzania). Four of the SW specimens from Germany were from the trademark brand RASKO, consisting of grades 00, 0, 1, 2. The other two German SW varieties were a stainless steel Topfreiniger and a variety from the trademark brand Bobby Mat. The Bobby Mat variety was a fine grade, while the grade of the stainless steel Topfreiniger was not specified, but is herein classified as 
coarse grade. The two SW purchased in Tengenru (produced in Kenya) included Champion and Sokoni trademark brands, both being of a fine grade. Five of the SW were purchased in Douala (Cameroon): Trademark brand Grand Menage extra fine and fine SW, trademark brand Socapine very fine SW, Magic Mamy trademark brand coarse SW, and a generic coarse SW. Additional two specimens were produced in China: Trademark brands Suprawisch fine grade SW and Lijia medium grade SW. The specifications of the SW specimens are summarized in Table 1. Apart from chopping the SW samples into pieces of 1-2 cm in length, all materials were used for the experiment in an 'as received' state.

Table 1. Overview of the fifteen different steel wool (SW) specimens used in the experiments. The SW vary from extra fine to coarse grade, and come from Germany, Kenya, Cameroon, and China. Information about SW thickness was deduced from the grade or given by the suppliers.

\begin{tabular}{ccccc}
\hline Material Code & Size & Grade & Thickness $(\mu \mathrm{m})$ & Trade Name \\
\hline SW1 & fine & 00 & 40 & RASKO (Germany) \\
\hline SW2 & medium & 0 & 50 & RASKO (Germany) \\
\hline SW3 & medium & 1 & 60 & RASKO (Germany) \\
\hline SW4 & medium & 2 & 75 & Champion (Kenya) \\
\hline SW5 & fine & 00 & 40 & SOKONI (Kenya) \\
\hline SW6 & fine & 00 & 40 & BOBBY MAT (Germany) \\
\hline SW7 & fine & 00 & 40 & Stainless steel Topfreiniger (Germany) \\
\hline SW8 & coarse & 2 & 75 & GOCAPINE (Cameroon) \\
\hline SW9 & fine & 00 & 40 & Stainless steel SUPRAWISCH (China) \\
\hline SW10 & extra fine & 000 & 35 & LIJIA (China) \\
\hline SW11 & fine & 0 & 50 & Grand Menage (Cameroon) \\
\hline SW12 & medium & 1 & 60 & MAGIC MAMY (Cameroon) \\
\hline SW13 & fine & 0 & 50 & Generic steel wool (Cameroon) \\
\hline SW14 & coarse & 2 & 95 &
\end{tabular}

\subsection{Experimental Procedure}

\subsubsection{Iron Dissolution in EDTA}

\section{Batch Experiments}

Two series of quiescent batch experiments were conducted at room temperature $\left(22 \pm 2{ }^{\circ} \mathrm{C}\right)$ in glass beakers and out of direct sunlight:

Experiment 1: The objective was to achieve the best possible linearity of the function $[\mathrm{Fe}]=\mathrm{f}(\mathrm{t})$. A $0.01 \mathrm{~g}$ sample of each steel wool (SW1-SW8) was weighed out and placed in $50 \mathrm{~mL}$ of $2 \mathrm{mM}$ EDTA solution. At prefixed intervals, $1 \mathrm{~mL}$ samples were taken from each of the beakers and analyzed for Fe.

Experiment 2: Triplicates of each of the following samples placed in beakers containing $50 \mathrm{~mL}$ of 2 mM EDTA solution: $0.01 \mathrm{~g}$ samples of SW1, SW5, SW9, and granular iron, in addition to a $0.1 \mathrm{~g}$ sample of granular iron. The average value of the corresponding triplicates was used for the discussion.

\section{Column Experiments}

Five glass columns were filled with $10 \mathrm{~cm}$ of sand, on top of which 0.500 grams of $\mathrm{Fe}^{0}$ material was placed. Each column contained one of the five types of $\mathrm{Fe}^{0}$ materials being tested. Four steel wool specimens (SW1, SW5, SW6, SW7) and the granular iron (GI) were selected and used. The columns 
were then intermittently charged with a gravity driven $2 \mathrm{mM}$ EDTA solution and allowed to set for at least $24 \mathrm{~h}$. About $300 \mathrm{~mL}$ of EDTA was added for each leaching event.

The EDTA solution from each column was then drained and collected in a glass cylinder 3-5 times per week. The collected volume was measured and recorded for each leaching event. An amount of 0.5 to $2.0 \mathrm{~mL}$ of the effluent solution was taken, extended to $10 \mathrm{~mL}$, and used for Fe determination. After each column was drained of EDTA solution it was refilled with newly prepared solution and the procedure was repeated. The experiment was performed at room temperature $\left(22 \pm 2{ }^{\circ} \mathrm{C}\right)$.

\subsubsection{Methylene Blue (MB) Discoloration}

These experiments involved eight $\mathrm{Fe}^{0} \mathrm{SW}$ (SW1 through SW8) and one GI, involving 10 different systems in triplicates. A total of 30 systems were characterized. Each system consisted of 0.00 or $0.05 \mathrm{~g}$ of the $\mathrm{Fe}^{0}$ specimen (one blank, one GI, and $8 \mathrm{SW}$ ), and $22 \mathrm{~mL}$ of MB. The initial MB concentration was $10 \mathrm{mg} \mathrm{L}^{-1}$. The 30 systems were placed in test tubes and were allowed to equilibrate on a rotary shaker at 75 rotations per min (rpm) for two or eight weeks. At the end of the equilibration, samples were then analyzed for $\mathrm{MB}$ concentration.

\subsubsection{Fluoride Removal}

\section{Batch Experiments}

Nine $\mathrm{Fe}^{0}$ specimens (SW1-SW8 and GI) were tested for fluoride removal under quiescent conditions for eight weeks. A triplicate set without $\mathrm{Fe}^{0}$ served as the reference system. Experiments were performed in triplicates. A total of 30 systems were tested. Test tubes were filled with a $25 \mathrm{mg} \mathrm{L}^{-1}$ fluoride solution. The average removal value of each sample triplicate was determined and used for the discussion.

\section{Column Experiments}

Five glass columns were filled with multiple layers of sand and sand/steel wool mixtures. An amount of $200 \mathrm{~mL}$ of sand was poured into the bottom of each column. To assure that the sand was optimally compacted the columns were gently tapped with a $100 \mathrm{~mL}$ PET flacon containing water. The reactive zone was placed on top of the sand layer. This reactive zone consisted of a total of 2.0 grams of steel wool mixed with $100 \mathrm{~mL}$ of sand. The investigated steel wool specimens were SW1, SW2, SW3, SW4, and SW6 (Table 2). The SW was cut into small pieces $(1-2 \mathrm{~cm}$ ) so that layers of sand could be interspersed between layers of steel wool. On top of the reactive layer, an additional $100 \mathrm{~mL}$ of sand was added (Figure 1).

Table 2. The selected metallic iron $\left(\mathrm{Fe}^{0}\right) \mathrm{SW}$ specimens for investigation in column studies with $25 \mathrm{mg} \mathrm{L}^{-1}$ fluoride solution. An amount of $2.0 \mathrm{~g}$ of each sample was cut into small pieces and placed in the reactive zone of its respective column.

\begin{tabular}{cccccc}
\hline & Column 1 & Column 2 & Column 3 & Column 4 & Column 5 \\
\hline Steel Wool & SW 1 & SW 2 & SW 3 & SW 4 & SW 6 \\
\hline Mass (g) & 1.985 & 1.989 & 2.006 & 2.009 & 1.996 \\
\hline
\end{tabular}

The columns were then charged with a gravity driven water solution containing $25 \mathrm{mg} \mathrm{L}^{-1}$ of fluoride (about $300 \mathrm{~mL}$ ). An amount of $15 \mathrm{~mL}$ of effluent from each column was collected in plastic sampling containers, after the fluoride solution had been in contact with the steel wool and sand filter for at least $24 \mathrm{~h}$. These effluent samples were used to determine the fluoride concentration, therefore only plastic containers, not glass, could be used. An additional $10 \mathrm{~mL}$ water sample from each column was collected in a glass test tube in order to determine iron concentration. The $\mathrm{pH}$ of the effluent was 
also determined and its total volume recorded. Each time after samples were taken for iron, fluoride, and $\mathrm{pH}$ determination, the columns were refilled with freshly prepared fluoride solution.

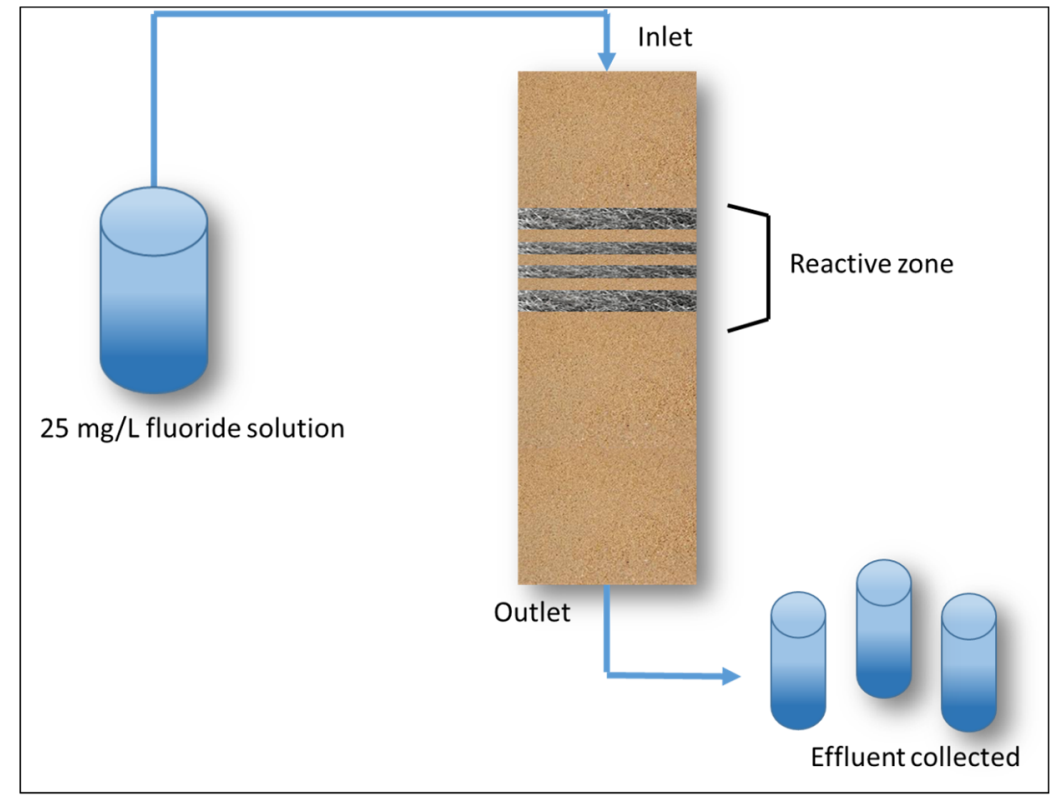

Figure 1. Graphic representation of the experimental setup of the fluoride removal experiment.

\subsection{Analytical Methods}

\subsubsection{UV-Vis Spectrophotometry}

A Cary 50 Varian UV-Vis spectrophotometer was used to determine MB and total dissolved iron concentration of the samples. The wavelength was set to 510 and $664.5 \mathrm{~nm}$ for dissolved iron and MB, respectively. Determination of dissolved iron followed the 1,10 orthopenanthroline method [61]. Iron samples were prepared by combining: $10 \mathrm{~mL}$ of sample $+1 \mathrm{~mL}$ ascorbic acid $+8 \mathrm{~mL} \mathrm{H}_{2} \mathrm{O}+1 \mathrm{~mL}$ 1,10-orthophenanthroline.

The UV-Vis spectrophotometer was calibrated for dissolved iron and MB using standard solutions of known concentrations. For iron determination, standard solutions of $0,2,4,6,8$, and $10 \mathrm{mg} \mathrm{L}^{-1}$ were prepared from a commercial iron standard solution. Calibration for MB was performed by using standard solutions of $0,2.5,5.0,7.5$, and $10 \mathrm{mg} \mathrm{L}^{-1}$.

\subsection{2. $\mathrm{pH}$ Meter}

The $\mathrm{pH}$ value of samples were measured with combined gas electrodes (WTW Co., Germany) which were calibrated with five standard solutions of known $\mathrm{pH}$ value in accordance with IUPAC recommendations [62]. A magnetic stir bar was placed in the beaker of each of the samples in order to homogenize the solution and prevent statistical error. The electrode measured the $\mathrm{pH}$ of each sample for at least $2 \mathrm{~min}$ before the data was recorded.

\subsubsection{Fluoride Electrode}

An ion selective electrode was used for the determination of fluoride from column effluents. A calibration curve was made by recording the potential values for the corresponding fluoride solutions of ten different concentrations: $0.00,1.25,2.50,5.00,7.50,10.00,15.00,20.00,25.00$, and $30.00 \mathrm{mg} \mathrm{L}^{-1}$. Total ionic strength adjustment buffer with a $\mathrm{pH}$ of 5.3 was used with fluoride solutions to reduce the interference of other ions (including $\mathrm{OH}^{-}$and $\mathrm{Fe}^{3+}$ ). The measured fluoride potentials were used to calculate fluoride concentrations. 


\subsection{Expression of Experimental Results}

\subsubsection{Kinetics of $\mathrm{Fe}^{0}$ Oxidative Dissolution ( $\mathrm{k}_{\mathrm{EDTA}}$ Value)}

The initial rate of iron dissolution from each $\mathrm{Fe}^{0}$ specimen is expected to follow a linear function (Equation (1)).

$$
[\mathrm{Fe}]=\mathrm{k}_{\mathrm{EDTA}} * \mathrm{t}+\mathrm{b}
$$

The regression parameters of the experimental data ( $\mathrm{EDTA}_{\text {EDA }}$ and") are characteristic for each $\mathrm{Fe}^{0}[47,63]$. Direct comparison of the calculated rates of iron dissolution ( $\mathrm{k}_{\text {EDTA }}$ ) could be used to indicate the more reactive SW materials, while the calculated intercept ( $\left.{ }^{\prime} b^{\prime}\right)$ values could be used to indicate the relative amount of pre-existing corrosion products present on the material surfaces. Linear parameters were determined using the Origin graphing software.

\subsubsection{Removal Efficiency (E Value)}

The changes in magnitude of the tested systems for $\mathrm{MB}$ discoloration and water defluoridation were calculated and presented as efficiency percentages (E value). Initial $\left(\mathrm{C}_{0}\right)$ and final $(\mathrm{C})$ concentration of the species were determined, and the following formula was used to calculate the removal efficiency:

$$
\mathrm{E}=\left[1-\left(\mathrm{C} / \mathrm{C}_{0}\right)\right] * 100 \%
$$

The operational initial concentration $\left(\mathrm{C}_{0}\right)$ for each case was acquired from a triplicate control experiment without additive material (blank). This procedure was mainly to account for experimental errors due to dye adsorption onto the walls of the test tubes.

\section{Results and Discussion}

\subsection{Iron Dissolution in EDTA}

\subsubsection{Appropriateness of the Experimental Approach}

Figure 2 compares the results of iron dissolution in $2 \mathrm{mM}$ EDTA for three $\mathrm{Fe}^{0} \mathrm{SW}$ and the GI. EDTA clearly dissolves far more iron from $\mathrm{Fe}^{0} \mathrm{SW}$ than from GI. The Fe dissolution kinetics was more rapid for SW as well. The deferential behaviour from Figure 2 is explained by considering the chemistry of the system. In fact, $\mathrm{Fe}^{0}$ is corroded by water $\left(\mathrm{H}_{2} \mathrm{O}\right.$ or $\left.\mathrm{H}^{+}\right)$according to Equation (3). Generated $\mathrm{Fe}^{2+}$ is further oxidized to $\mathrm{Fe}^{3+}$ ions by dissolved $\mathrm{O}_{2}$ (Equation (4)). In essence, $\mathrm{Fe}^{3+}$ is available as $\mathrm{Fe}\left(\mathrm{H}_{2} \mathrm{O}\right)_{6}{ }^{3+}$ which tend to polymerize and precipitate as $\mathrm{Fe}(\mathrm{OH})_{3}$ but under the conditions of this study $\mathrm{H}_{2} \mathrm{O}$ is replaced by EDTA that form very stable complexes with $\mathrm{Fe}^{3+}$ (Equation $\left.(5)\right)[64,65]$. In other words, $\mathrm{Fe}(\mathrm{OH})_{3}$ precipitation will not occur before the solution is saturated $\left([\mathrm{Fe}]=112 \mathrm{mg} \mathrm{L}^{-1}\right)$. Figure 2 shows that for the SW specimens, saturation occurs after $50 \mathrm{~h}$ and $[\mathrm{Fe}]=\mathrm{f}(\mathrm{t})$ is no more linear. For GI no saturation occurs even after $140 \mathrm{~h}$.

$$
\begin{gathered}
\mathrm{Fe}^{0}+2 \mathrm{H}^{+} \Rightarrow \mathrm{Fe}^{2+}+\mathrm{H}_{2} \\
4 \mathrm{Fe}^{2+}+2 \mathrm{H}^{+}+\mathrm{O}_{2} \Rightarrow 4 \mathrm{Fe}^{3+}+2 \mathrm{OH}^{-} \\
\mathrm{Fe}^{3+}+\text { EDTA } \Rightarrow \mathrm{Fe}(\mathrm{EDTA})^{3+}
\end{gathered}
$$




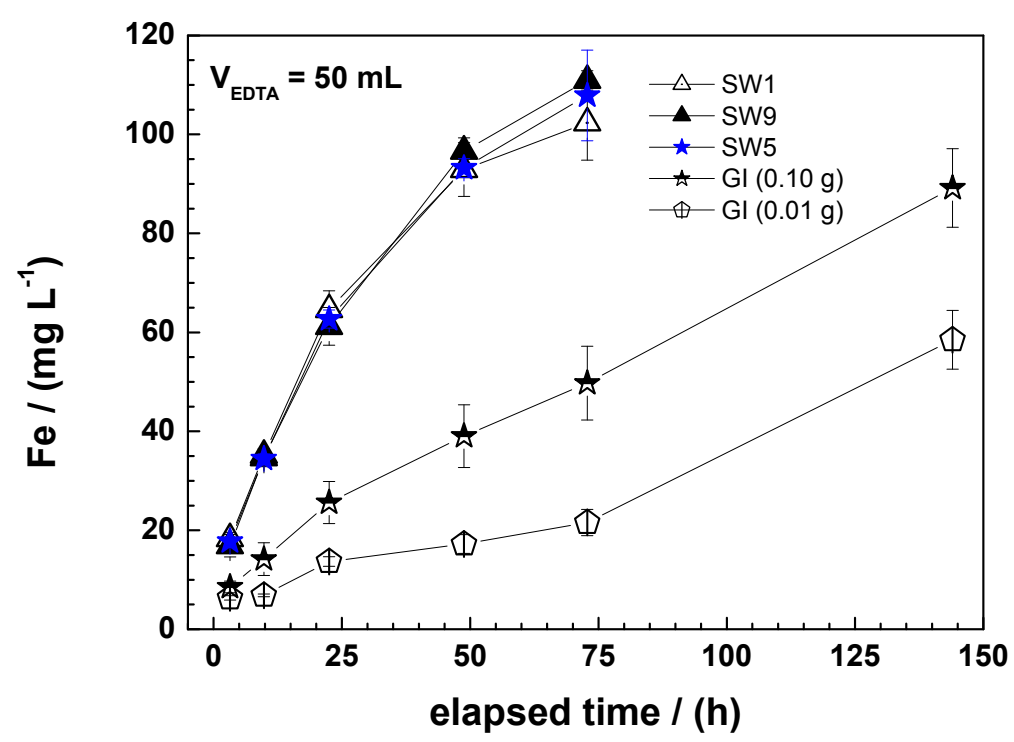

Figure 2. Time-dependent iron dissolution from (i) $0.01 \mathrm{~g}$ of SW1, SW5, and SW9 and (ii) 0.01 and $0.10 \mathrm{~g}$ of granular iron (GI). All regression parameters for $0.01 \mathrm{~g} \mathrm{Fe}^{0}$ are listed in Table 3. The represented lines are not fitting functions, they just join the points to facilitate visualization.

Table 3. Corresponding correlation parameters $\left(\mathrm{k}_{\mathrm{EDTA}}, \mathrm{b}, \mathrm{R}^{2}\right)$ for SW1-SW12 and granular iron. As a rule, the more reactive a material is under given conditions, the higher the $k_{\text {EDTA }}$ value. $R^{2}$ is a correlation factor. General conditions: $50 \mathrm{~mL}$ of $2 \mathrm{mM}$ EDTA solution and $0.01 \mathrm{~g} \mathrm{Fe}^{0}$. $\mathrm{K}_{\mathrm{EDTA}}$, b, and $\mathrm{R}^{2}$ were calculated using Origin 8.0.

\begin{tabular}{cccc}
\hline Fe $^{\mathbf{0}}$ & $\mathbf{k}_{\text {EDTA }}$ & $\mathbf{b}$ & $\mathbf{R}^{\mathbf{2}}$ \\
\hline & $\left(\mu \mathrm{g} \mathrm{h}^{-1}\right)$ & $(\mu \mathrm{g})$ & $(-)$ \\
\hline SW 1 & 78.4 & 552.9 & 0.8851 \\
\hline SW 2 & 111.7 & 160.0 & 0.9984 \\
\hline SW 3 & 113.0 & 435.8 & 0.9761 \\
\hline SW 4 & 110.9 & 322.4 & 0.9873 \\
\hline SW 5 & 106.9 & 393.0 & 0.9707 \\
\hline SW 6 & 130.8 & 282.6 & 0.9881 \\
\hline SW 7 & 112.6 & 261.6 & 0.9960 \\
\hline SW 8 & 0.0 & 0.0 & n.a. \\
\hline SW9 & 84.9 & 289.4 & 0.9944 \\
\hline SW10 & 108.3 & 516.7 & 0.9970 \\
\hline SW11 & 0.0 & 0.0 & n.a. \\
\hline SW12 & 28.7 & 77.9 & 0.9838 \\
\hline SW13 & 31.2 & -170.8 & 0.8010 \\
\hline SW14 & 24.4 & -138.4 & 0.9583 \\
\hline SW15 & 20.1 & 132.6 & 0.7427 \\
\hline GI & 3.7 & -10.3 & 0.9396 \\
\hline
\end{tabular}

$\mathrm{Fe}^{0}$ oxidative dissolution in water or aqueous iron corrosion is spontaneous because the electrode potential of water $\left(\mathrm{E}^{0}=0.00 \mathrm{~V}\right.$ for $\left.\mathrm{H}^{+} / \mathrm{H}_{2}\right)$ is larger than that of $\mathrm{Fe}^{0}\left(\mathrm{E}^{0}=-0.44 \mathrm{~V}\right)$. However, $\mathrm{E}^{0}=-0.44 \mathrm{~V}$ is valid for all reactive $\mathrm{Fe}^{0}$-bearing materials. In other words, material specific characteristics will determine the kinetics of $\mathrm{Fe}^{0}$ dissolution. Dannenberg and Potter [15] reported on specific surface areas 
(SSA) of 120, 100, and $50 \mathrm{~cm}^{2}$ for grades $0(\mathrm{~d}=50 \mu \mathrm{m}), 1(\mathrm{~d}=60 \mu \mathrm{m})$, and $2(\mathrm{~d}=75 \mu \mathrm{m}) \mathrm{Fe}^{0} \mathrm{SW}$. This suggests that, rooting the reasoning on the SSA alone, a reactivity ratio of 2 is expected when grades 1 and 2 are used in any application. There are seven classes of $\mathrm{Fe}^{0} \mathrm{SW}$ depicting thicknesses of the SW filament (d) varying from 25 to $100 \mu \mathrm{m}$ [12]. Therefore, it is essential to comparatively characterize their reactivity in order to ease their selection for site-specific designs.

Figure 2 clearly shows that GI is dissolved with a far lower dissolution rate than the three presented SW specimens. Two different masses of GI are used (0.1 and $0.01 \mathrm{~g})$ while the used mass of SW was $0.01 \mathrm{~g}$. With regard to the linearity of the $[\mathrm{Fe}]=\mathrm{f}(\mathrm{t})$ function, it is evident that longer experimental durations are needed for GI (up to four days) while SW characterization is achieved within $24 \mathrm{~h}$. Previous works have demonstrated that the linearity of Equation (1) is difficult to be obtained with fine $\mathrm{Fe}^{0}$ materials and with those covered with iron corrosion products. The reason being that EDTA dissolves Fe ${ }^{\mathrm{III}}$ species as well [12]. The next section presents the tools utilized herein to obtain reasonable $\mathrm{k}_{\mathrm{EDTA}}$ values. It should be explicitly stated that Figure 2 illustrates the differential behaviour of SW and GI. The expected trend of more rapid Fe dissolution from smaller particles is documented. The next result is that material of diverse coarseness cannot be characterized under the same experimental conditions using the EDTA test [12].

\subsection{2. $\mathrm{k}_{\mathrm{EDTA}}$ Values}

The results of the conventional EDTA test $\left(0.1 \mathrm{~g} \mathrm{Fe}^{0}\right.$, four days) for SW1 to SW8 are summarized in Figure 3a. Except from nonreactive SW8 (stainless steel), all materials depicted very similar dissolution rates and therefore are not easily distinguishable. There is no linear trend in the dissolution rates of all reactive SW specimens, which makes classification of dissolution efficiency impossible. The cause for the nonlinearity is the higher reactivity of SW and the presence of atmosphereic FeCPs on their surface $[12,47]$. Two major modifications were made to achieve reasonable $k_{\text {EDTA }}$ values: (i) Lowering the mass of $\mathrm{Fe}^{0} \mathrm{SW}$ to 0.04 and 0.01 , and increasing the volume of the EDTA solution to $100 \mathrm{~mL}$ [45]. The tested materials could be roughly grouped in three different classes: (i) Nonreactive (SW8), (ii) low reactive (SW1, SW2, SW3, SW4), and (iii) very reactive (SW5, SW6, SW7). After achieving optimal test conditions with the $8 \mathrm{Fe}^{0} \mathrm{SW}$ the remaining seven specimens and GI were tested using $0.01 \mathrm{~g} \mathrm{SW}$ and $50 \mathrm{~mL}$ of the EDTA solution (Figure $3 \mathrm{~b}$ ). The results for all tested $16 \mathrm{Fe}^{0}$ specimens are summarized in Table 3.

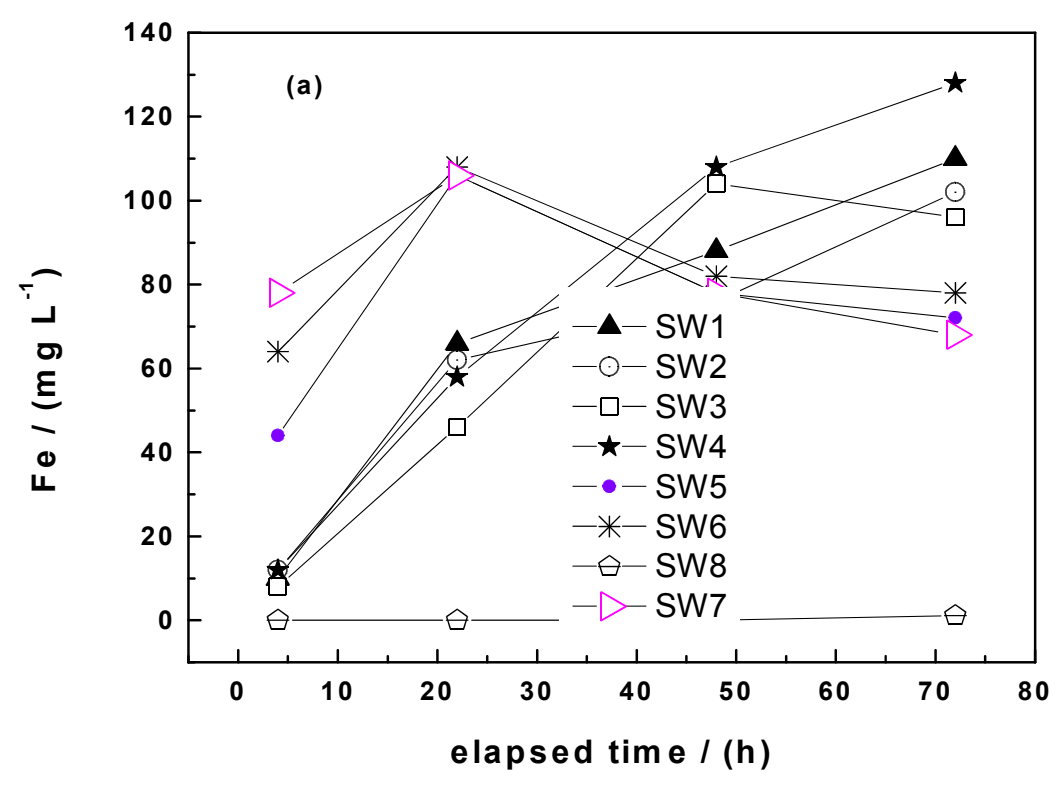

Figure 3. Cont. 


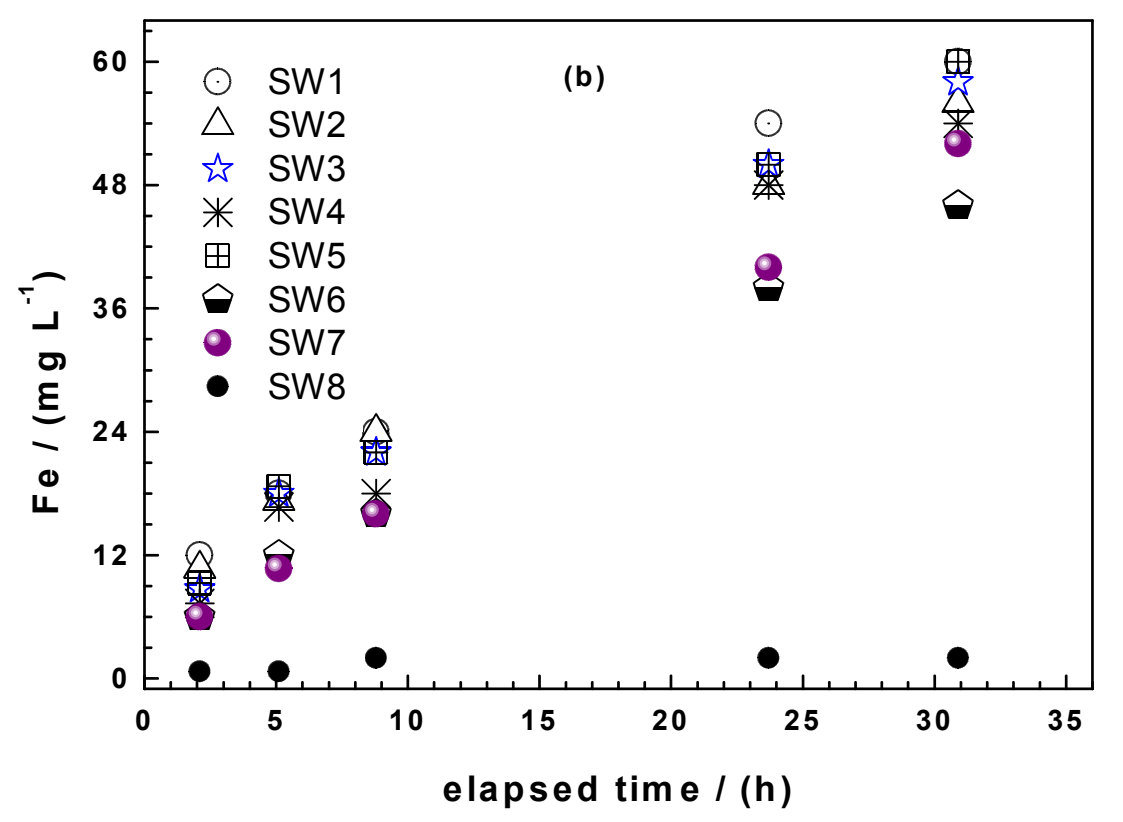

Figure 3. Comparison of the dissolution rate of eight steel wool specimens (SW1 to SW8) in $50 \mathrm{~mL}$ of a $2 \mathrm{mM}$ ethylenediaminetetraacetate (EDTA) solution under quiescent conditions for up to $70 \mathrm{~h}$. Experimental conditions: (a) $\mathrm{m}_{\mathrm{SW}}=0.10 \mathrm{~g}$, and (b) $\mathrm{m}_{\mathrm{SW}}=0.01 \mathrm{~g}$. The represented lines are not fitting functions; they just connect the points to ease visualization.

Figure 3b shows clearly that: (i) SW8 is nonreactive, (ii) SW6 and SW7 are less reactive than the five other materials, and (iii) the reactivity of the five remaining materials cannot be visually achieved. The regression parameters for all tested materials are summarized in Table 3 and the value of $\mathrm{k}_{\text {EDTA }}$ is used to classify the reactivity of the $\mathrm{Fe}^{0} \mathrm{SW}$ which are collectively far higher than that of GI. Table 3 shows that SW8 and SW 11 are nonreactive. The $\mathrm{k}_{\text {EDTA }}$ values for SW12 to SW15 were lower than $30 \mu \mathrm{g} \mathrm{h}^{-1}$ and they are considered as low reactive. The $\mathrm{k}_{\mathrm{EDTA}}$ values for SW1 and SW9 are 78.4 and $84.9 \mu \mathrm{g} \mathrm{h}^{-1}$, respectively, they are operationally considered as middle reactive. For the remaining $\mathrm{Fe}^{0}$ SW specimens the $\mathrm{k}_{\text {EDTA }}$ values were larger than $100 \mu \mathrm{g} \mathrm{h} \mathrm{h}^{-1}$ and they are considered as very reactive. The remaining reasoning is focused on SW1 to SW7 while considering SW8 and GI as "negative" reference. Low reactive $\mathrm{Fe}^{0} \mathrm{SW}$ were also not further considered because they were all not from the local marked (Table 1). The objective of leaching in column studies was to check whether a better differentiation of three materials (SW5, SW6, and SW7) from the class "very reactive" was possible. For comparison one "middle reactive" material (SW1) and GI were considered.

\subsubsection{Column Leaching Studies}

Figure 4a shows that the four $\mathrm{Fe}^{0} \mathrm{SW}$ exhibited markedly increased iron dissolution during the whole experiments (53 leaching events) than GI. It is also seen that there are picks in the iron concentration. Hildebrant [45] demonstrated that the picks did not correspond to longer standing times (e.g., weekends values with $72 \mathrm{~h}$ of equilibration). It is also seen that the saturation value $\left(112 \mathrm{mg} \mathrm{L}^{-1}\right)$ for iron was never achieved. The last important observation from Figure $4 \mathrm{a}$ is that there are waves in the kinetics of iron dissolution. The most remarkable pick is the one for GI around the 20th leaching event. Here, GI suddenly release more Fe than SW6 which is the most reactive material according to the $\mathrm{k}_{\mathrm{EDTA}}$ values. It is not worth trying to rationalize this behaviour, it is enough to document it at this stage and look in the future if such results are reported. Similarly as the EDTA test, absolute Fe concentrations are needed to differentiate the reactivity of the $\mathrm{Fe}^{0} \mathrm{SW}$. 
Figure $4 \mathrm{~b}$ summarizes the cumulative amount of Fe leached from each column. GI is the least reactive material for the whole 53 leaching events. Interestingly, until the 6th event, all the four $\mathrm{Fe}^{0}$ SW specimens behaved very similarly with SW7 releasing slightly more iron. Afterwards, SW7 was constantly the most reactive material while SW1 and SW5 behaved very similarly and constantly better than SW6. In other words, SW6, the best material according to the $\mathrm{k}_{\mathrm{EDTA}}$ value, is the least reactive from the $4 \mathrm{Fe}^{0} \mathrm{SW}$ considered in column leaching experiments. This observation corroborates the need for long-term experiments in testing $\mathrm{Fe}^{0}$ materials for environmental remediation and water treatment.

Another important issue from Figure $4 \mathrm{~b}$ is the change of the slopes of all materials: For GI already after some five leaching events, for SW1 after 16 leaching events and for the three other after 40 events. These results elegantly demonstrate the nonlinearity of the kinetic of iron corrosion under conditions where there is no oxide scale on $\mathrm{Fe}^{0}$. Under field conditions, the precipitation of iron hydroxide and the myriad of processes that influence its stability are certainly as site-specific as the water to be treated. For this reason at least, there should be unified reductionists protocol to characterize the intrinsic reactivity of $\mathrm{Fe}^{0}$ materials relevant for field applications.

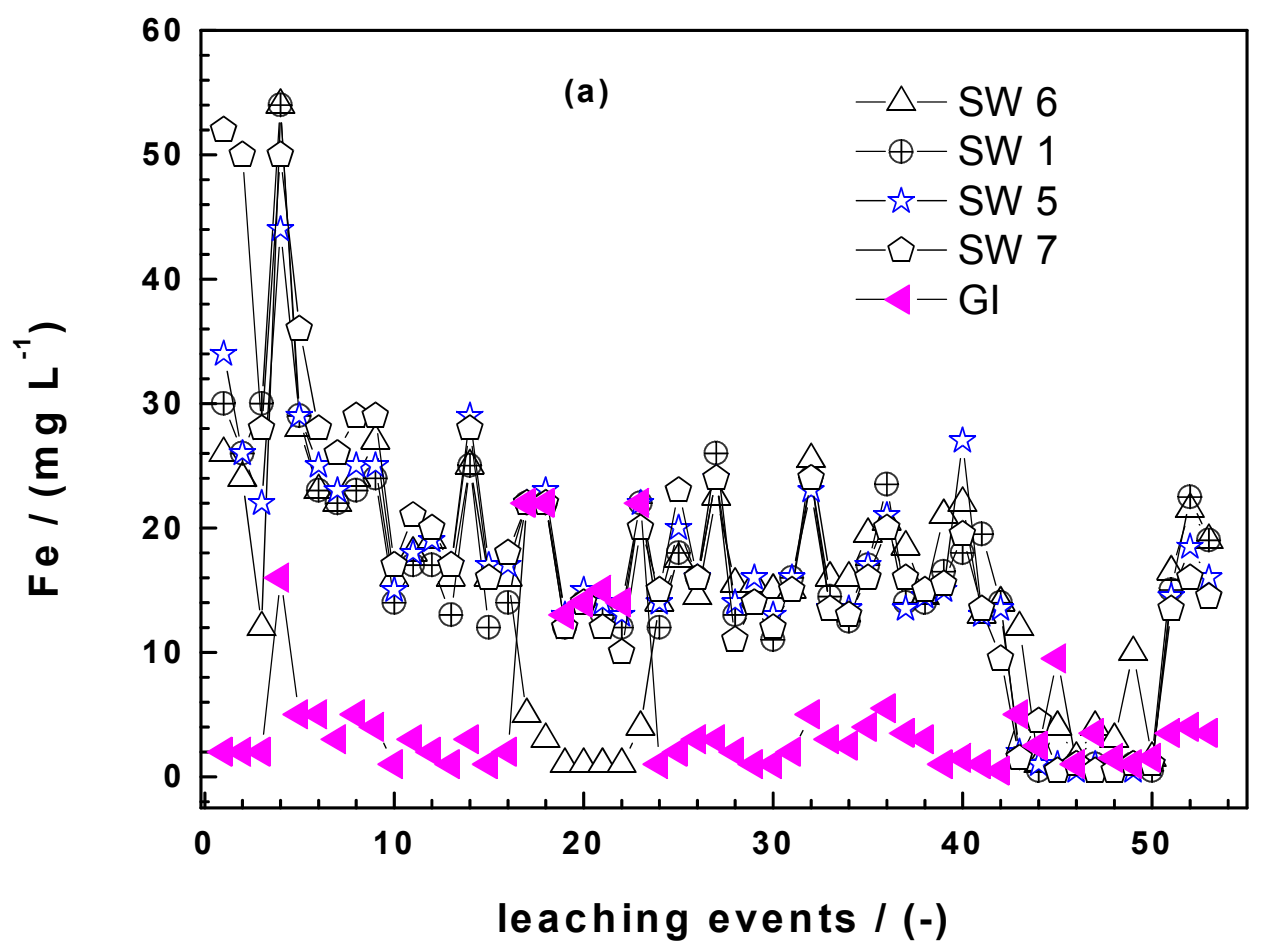

Figure 4. Cont. 


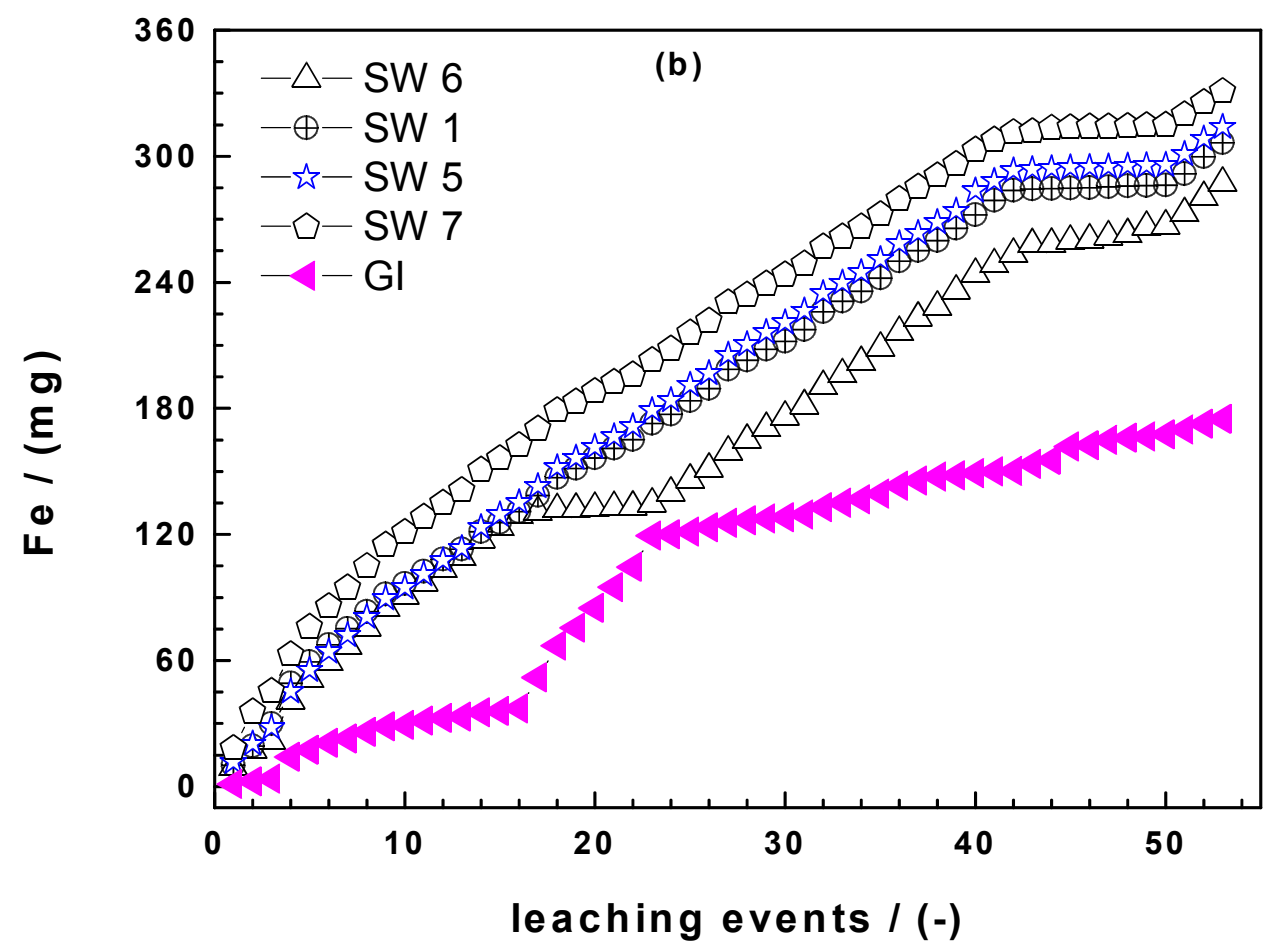

Figure 4. Comparison of the extent of iron dissolution in column leaching experiments for SW1, SW5, SW6, SW7, and GI: (a) Iron concentration and (b) cumulative mass of dissolved iron. Experimental conditions: $\mathrm{m}_{\text {iron }}=0.500 \mathrm{~g}$, [EDTA] $=2 \mathrm{mM}$.

\section{2. $M B$ Discoloration}

Figure 5a summarizes the results of MB discoloration after two weeks. It confirms that SW8 is not reactive and $\mathrm{Fe}^{0} \mathrm{SW}$ perform better than GI. From the $\mathrm{Fe}^{0} \mathrm{SW}$ specimens, SW5 performed the best. SW1, SW3, and SW4 were very similar in their E values and performed slightly lower than SW6, SW2, and SW7. It is recalled that only grade 00 (fine $-\mathrm{d}=40 \mu \mathrm{m}$ ) materials were used in column leaching experiments (Table 1), together with GI. The order of efficiency as related by the mean E values is the following:

GI $<$ SW1 $(\mathrm{d}=40 \mu \mathrm{m})<\mathrm{SW} 3<\mathrm{SW} 4<\mathrm{SW6}(\mathrm{d}=40 \mu \mathrm{m})<\mathrm{SW} 2<\mathrm{SW7}(\mathrm{d}=40 \mu \mathrm{m})<\mathrm{SW} 5$ $(\mathrm{d}=40 \mu \mathrm{m})$, following the extent of Fe leaching in columns the order was:

GI $<$ SW6 $(\mathrm{d}=40 \mu \mathrm{m})<\mathrm{SW} 1(\mathrm{~d}=40 \mu \mathrm{m})<\mathrm{SW} 5(\mathrm{~d}=40 \mu \mathrm{m})<\mathrm{SW7}(\mathrm{d}=40 \mu \mathrm{m})$.

The only constant for both classifications is that GI is the least performant material. However, considering the standard deviations (error bars), the classification of MB discoloration can be rewritten as:

$\mathrm{GI}<\mathrm{SW} 1 \cong \mathrm{SW} 3 \cong \mathrm{SW} 4 \cong \mathrm{SW} 6<\mathrm{SW} 2 \cong \mathrm{SW} 7 \cong \mathrm{SW} 5$.

Accordingly, there is a direct correlation between the extent of iron dissolution and the extent of $\mathrm{MB}$ discoloration. This correlation is obvious, given that $\mathrm{MB}$ is mainly removed by coprecipitation with $\mathrm{FeCPs}$ of very low affinity to MB. Under the same experimental conditions, Hildebrant [45] reported on quantitative removal of methyl orange with no significant difference is the $\mathrm{E}$ values for all $\mathrm{Fe}^{0}$ SW specimens.

Figure $5 \mathrm{~b}$ summarizes the results of $\mathrm{MB}$ discoloration after eight weeks (two months). It is seen that the longer experimental duration enabled quantitative $\mathrm{MB}$ discoloration by all $\mathrm{Fe}^{0} \mathrm{SW}$ specimens. The main feature from Figure $5 b$ is that whenever enough FeCPs is produced, contaminant removal is quantitative. Actually, $\mathrm{Fe}^{0}$ materials are used for water treatment without any idea on their intrinsic reactivity nor their long-term kinetics of corrosion. This is the main reason why despite 170 years of technical expertise, designing an efficient and sustainable system is still an exception. 

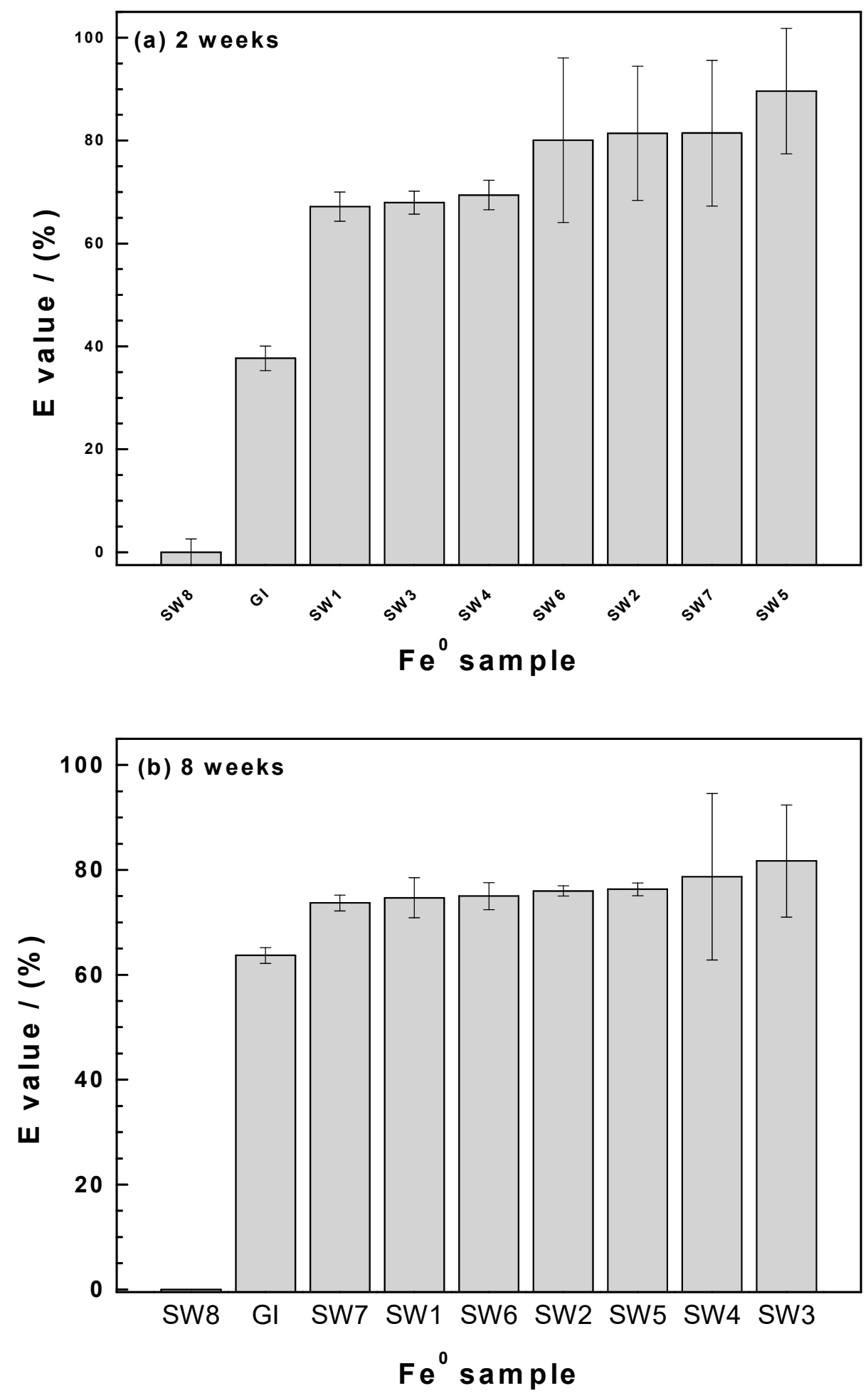

Figure 5. Extent of methylene blue discoloration for SW1-SW8 and GI after (a) two weeks and (b) eight weeks. Experimental conditions: $\left.0.05 \mathrm{~g} \mathrm{Fe}^{0} ; \mathrm{V}=22 \mathrm{~mL} ; \mathrm{MB}\right]=10 \mathrm{mg} / \mathrm{L}$; rotational shaking at 75 rotations per min. 


\subsection{Water Defluoridation}

\subsubsection{Batch Experiments}

Figure 6a summarizes the results of fluoride removal in quiescent batch experiments for two weeks. The results depict very limited water defluoridation $(\mathrm{E}<20 \%)$. This corroborates recent results by [66-68]. Knowing the less efficiency of $\mathrm{GI}$ for $\mathrm{F}^{-}$removal, the experiments were designed to investigate whether filamentous SW can perform better. The order of reactivity based on the mean values in Figure 6a enables the following order of reactivity:

SW8 (nonreactive) $<$ SW7 $<$ SW $6<$ SW3 $<$ SW $4<$ SW5 $<$ SW2 $<$ SW1

It is surprising that SW1, representative for the "low reactive" materials exhibited the highest removal performance. The difference is significant even when the standard deviation is considered. This is another reproducible result, that can only be documented while hoping that future works would enable a better explanation. The impression here is that it seems that the most reactive material is not the best for water defluoridation. This would suggest that coprecipitation is not the main removal mechanism or that nascent iron hydroxides cannot not mediate $\mathrm{F}^{-}$removal. The results of column experiments seem to confirm this trend.

\subsubsection{Column Experiments}

Figure $6 \mathrm{~b}$ summarizes the results of fluoride removal in column experiments for 44 leaching events. It is seen that the best fluoride removal for each system was achieved during the very first leaching even, reaching $70 \%$ for SW1. Afterwards, E decreased to values lower than $30 \%$ with two picks at $(\mathrm{E}>30 \%)$ at the 27th and the 40th leaching event. In these two situations, SW1 was constantly the best material. Hildebrant [45] calculated the cumulative percent $\mathrm{F}^{-}$removal during the whole leaching experiments and obtained the following results:

SW1 $(18.3 \%)<$ SW2 $(16.6 \%)<$ SW3 $(15.2 \%)<$ SW4 $(12.3 \%)<$ SW6 $(11.2 \%)$.

These results suggest that fluoride removal by ion exchange onto "aged" FeCPs is more important than fluoride coprecipitation with nascent iron hydroxides. This observation excellently explained the results of Heimann [66] who documented $20 \%$ fluoride removal in a column experiment using $100 \mathrm{~g}$ of the GI used herein and no removal while changing the water flow velocity. More importantly, these results explain the enigma, why aged iron oxides and laterite are efficient for water defluoridation and $\mathrm{Fe}^{0}$ not (or less) as summarized in Heimann et al. [67].

Figure $6 \mathrm{~b}$ also confirms "waves" in the kinetics of $\mathrm{Fe}^{0} \mathrm{SW}$ efficiency with the net difference that maxima correspond to minima in the EDTA leaching experiments. The most important information from these investigations is that it is possible to manufacture specific iron oxides for water defluoridation [69]. Whenever this would not be affordable for small communities, it would be an attractive process for industrial and mining wastewater. 

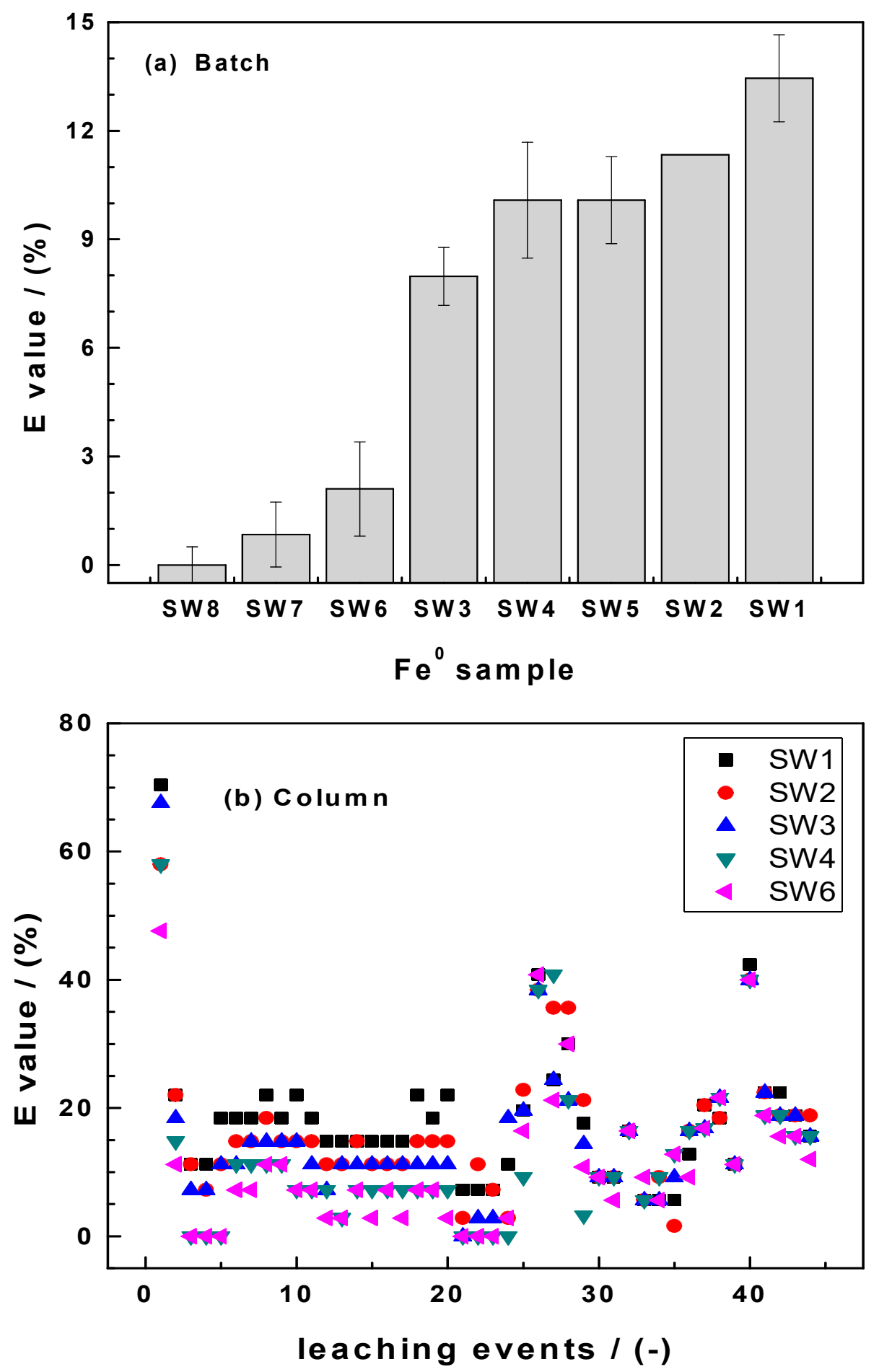

Figure 6. Extent of water defluoridation in (a) batch experiments and (b) intermittent column filtration. Experimental column conditions: $2.0 \mathrm{~g} \mathrm{Fe}^{0} \mathrm{SW} ; \mathrm{V}=22 \mathrm{~mL} ;\left[\mathrm{F}^{-}\right]=25 \mathrm{mg} / \mathrm{L}$.

\subsection{Discussion}

\subsubsection{Research in Progress}

The efficiency of $\mathrm{Fe}^{0} / \mathrm{H}_{2} \mathrm{O}$ systems for water treatment under natural conditions $(\mathrm{pH}>5.0)$ is influenced by a myriad of factors, of which the presence and the amount of dissolved $\mathrm{O}_{2}$ can be regarded as the most important [70]. $\mathrm{A} \mathrm{Fe} / \mathrm{H}_{2} \mathrm{O}$ system is grounded on a redox process which is $\mathrm{Fe}^{0}$ 
oxidative dissolution by water $\left(\mathrm{H}^{+}\right.$or $\left.\mathrm{H}_{2} \mathrm{O}\right) . \mathrm{Fe}^{0}$ is oxidized by water and its surface is covered by an oxide scale containing reducing agents (e.g., $\mathrm{H}_{2}, \mathrm{Fe}^{\mathrm{II}}$, and $\mathrm{Fe}^{\mathrm{II}} / \mathrm{Fe}^{\mathrm{III}}$ species). The nature and the permeability of the oxide scale depend on the abundance of dissolved $\mathrm{O}_{2}$ [71,72]. The abundance and the nature of iron hydroxides and oxides within the oxide scale influence the efficiency of each system for water treatment and additionally depends on the nature of the contaminants (e.g., speciation) [59].

The low adsorptive affinity of methylene blue (MB) for the oxide scale $\left(\mathrm{on} \mathrm{Fe}^{0}\right.$ ) has been almost routinely used to characterize the dynamic nature of the $\mathrm{Fe}^{0} / \mathrm{H}_{2} \mathrm{O}$ system $[47,49]$. The present study has identified water defluoridation as another reactive tracer for the $\mathrm{Fe}^{0} / \mathrm{H}_{2} \mathrm{O}$ system. Fluoride removal by nascent iron hydroxide is absolutely nonfavorable while $\mathrm{MB}$ discoloration occurs at a low rate. Thus, combining the two tools in long term column experiments seems to be the new avenue to investigate the long-term efficiency of $\mathrm{Fe}^{0} / \mathrm{H}_{2} \mathrm{O}$ systems in an affordable manner. The affordability of the approach results from the fact that just a fluoride electrode is added to the standard laboratory equipment. MB discoloration and water defluoridation identify waves in the iron dissolution kinetics, re-demonstrating the nonlinear nature of the kinetic of iron corrosion [73]. Moreover, the results suggest that iron corrosion in a field $\mathrm{Fe}^{0} / \mathrm{H}_{2} \mathrm{O}$ system is a stochastic process [49] which should be better characterize before been implemented in predictive models. This is probably the next major challenge of the $\mathrm{Fe}^{0}$ remediation research community as Santisukkasaem and Das [74] recently demonstrated the inadequacy of all available models to cope with the complex nature of the $\mathrm{Fe}^{0} / \mathrm{H}_{2} \mathrm{O}$ system. However, the nondimensional analysis of the permeability loss they suggested is equally not a stand-alone solution because the real cause of permeability loss is not important for their model. Before moving to such simplistic models, a science-based analysis of the $\mathrm{Fe}^{0} / \mathrm{H}_{2} \mathrm{O}$ system should be performed. In these investigations the nonlinear kinetic of $\mathrm{Fe}^{0}$ corrosion should be given a capital importance.

Properly selecting the material used in individual applications is very important. For example, while testing $\mathrm{Fe}^{0} \mathrm{SW}$ for household water treatment, Bradley et al. [42] realized that there was a $\mathrm{Fe}^{0}$ complete depletion of grade 0000 (extra fine- $d=25 \mu \mathrm{m}$ ) after six months (170 days). Tepong-Tsindé et al. [43] tested grade 0 (fine $-\mathrm{d}=50 \mu \mathrm{m}$ ) for 12 months and have not achieved any material depletion. The four $\mathrm{Fe}^{0} \mathrm{SW}$ (Table 1) tested in column leaching experiments herein were depleted to $57.5 \%$ to $66.2 \%$ after 53 leaching even. Future work should identify the time frame (or the number of leaching events) needed for complete depletion of various classes of $\mathrm{Fe}^{0} \mathrm{SW}$ using the EDTA and the Phen leaching experiments [12]. The results of such experiments would be a better way to predict the service life of $\mathrm{Fe}^{0} \mathrm{SW}$ specimens than each theoretical estimation. Moreover, characterized materials will be also useful for other applications (e.g., biogas purification) [75-77].

$\mathrm{Fe}^{0} \mathrm{SW}$ has been suggested and used for $\mathrm{H}_{2} \mathrm{~S}$ removal from biogas [75-77]. The work conducted until now to identify the characteristics of these materials for the named application has not been systematic. In particular, SW selection was not addressed. For example, photographs presented by Magomnang and Villanueva [76] suggest that the material they used was close to SW12 tested herein (Table 1) and characterized as "low reactive". This suggests that, following the principle of Notter [4] it suffices to work with the same design while using a more reactive material (e.g., SW7) to achieve a better quality of biogas. Clearly the tool presented herein will also facilitate the design of $\mathrm{Fe}^{0}$-based filters for biogas purification. Another important field of application is the production of small amounts of $\mathrm{H}_{2}$ to initiate biological processes (e.g., at laboratory scale) [refs].

\subsubsection{Significance of the Results}

Metallic iron is oxidized in $\mathrm{Fe}^{0} / \mathrm{H}_{2} \mathrm{O}$ systems to ferrous ion and $\mathrm{H}_{2}$. Ferrous ion migrates and precipitates at the surface of other aggregates (e.g., in situ coating of sand or zeolite). Iron oxide coated aggregates fix contaminants by adsorption and coprecipitation. In column systems, iron oxides fill the porous volume and improve contaminant removal by size-exclusion [78-80]. That is the thermodynamic of all $\mathrm{Fe}^{0} / \mathrm{H}_{2} \mathrm{O}$ systems. It should be added that $\mathrm{Fe}^{0}$ corrosion in an $\mathrm{O}_{2}$ scavenging process implying that oxidation of $\mathrm{Fe}^{0}$ contributes to produce anoxic conditions [81]. The extent to which $\mathrm{O}_{2}$ scavenging is achieved implies that some removal processes (e.g., denitrification) are just 
indirectly mediated [43]. In other words, the thermodynamic of the $\mathrm{Fe}^{0} / \mathrm{H}_{2} \mathrm{O}$ system implies that $\mathrm{Fe}^{0}$ can be universally used for: (i) $\mathrm{H}_{2}$ generation, (ii) $\mathrm{O}_{2}$ consumption, and (iii) generation of FeCPs (iron hydroxides and oxides). FeCPs are contaminant scavengers and this property was documented for a very long time [1]. The fact that some contaminants are reduced in $\mathrm{Fe}^{0} / \mathrm{H}_{2} \mathrm{O}$ systems is not discussed herein. It is just recalled that $\mathrm{H}_{2}$ and $\mathrm{Fe}^{\mathrm{II}}$ and $\mathrm{Fe}^{\mathrm{II}} / \mathrm{Fe}^{\mathrm{III}}$ species are stand-alone reducing agents $[28,79,80]$. The open question is how to design an efficient and sustainable $\mathrm{Fe}^{0} / \mathrm{H}_{2} \mathrm{O}$ system.

The efficiency of a $\mathrm{Fe}^{0} / \mathrm{H}_{2} \mathrm{O}$ system for water decontamination primary depends on three key factors: (i) The nature and the extent of water contamination, (ii) the extent to which decontamination should occur, and (iii) the rate at which contaminant scavengers (here FeCPs) are made available. Previous works have paid clearly low attention to the corrosion rates. This study shows that, the $\mathrm{k}_{\text {EDTA }}$ values for the tested $\mathrm{Fe}^{0} \mathrm{SW}$ varies from 20.1 to $130.8 \mu \mathrm{g} \mathrm{h}^{-1}$ (Table 3). This corresponds to a reactivity ratio of about $1 / 6$. However, the $\mathrm{k}_{\mathrm{EDTA}}$ values were determined in experiments lasting for just three days and correspond at best to the initial kinetics of iron corrosion which is well-known to be nonlinear [43,73]. The results of long-term leaching presented herein (Section 3.1.3) have documented waves (even) in this initial corrosion rate. Therefore, it is imperative to characterize the long-term reactivity of $\mathrm{Fe}^{0}$ materials, including $\mathrm{Fe}^{0} \mathrm{SW}$.

There have been very scare attempts to systematically characterize the effects of operational parameters on the efficiency of $\mathrm{Fe}^{0} / \mathrm{H}_{2} \mathrm{O}$ systems for water treatment. To the best of the author's knowledge, Dannenberg and Potter [15] have presented the most extensive investigations for $\mathrm{Fe}^{0} \mathrm{SW}$. The authors devised and successfully tested a $\mathrm{Fe}^{0} \mathrm{SW}$ based system for the recovery of silver from waste solutions. The following operational parameters were characterized at laboratory and pilot scale testing: (i) The SW grade or type (e.g., coarseness of filaments), (ii) the $\mathrm{pH}$ of the wastewater, (iii) the solution chemistry (e.g., concentrations of major ions), (iv) the flow rate, (v) the flow continuity (continuous flow versus intermittent), (vi) the packing density in the $\mathrm{Fe}^{0} \mathrm{SW}$ units, and (vi) the size of the $\mathrm{Fe}^{0} \mathrm{SW}$ units. In particular, Dannenberg and Potter [15] tested SW grades 0,1 , and 2 having approximate specific surface areas of 120,100, and $50 \mathrm{~cm}^{2} \mathrm{~g}^{-1}$ respectively and established that the $\mathrm{Fe}^{0}$ SW size do affect the decontamination capacity. The most important information from Dannenberg and Potter [15] is that, under specific conditions, the SW grade is a stand-alone efficiency parameter. The results of MB and MO discoloration achieved by Hildebrant [45] demonstrate how the nature of the contamination is essential in designing an efficient system. Even the results of water defluoridation presented herein confirm this assertion. In essence, given that it is the aqueous iron corrosion that implies decontamination, the sole open issue is designing efficient systems and this was already postulated in 1878 by Notter [4].

According to Notter [4], the success of any designed filter depends on: (i) The quantity and quality of the water to be treated, (ii) the characteristics of the filtering media, (iii) the speciation of the contaminants(s), and (iv) the regenerability of the filtering material readily. Applying the principles to $\mathrm{Fe}^{0}$-based filters, it could be said that it is time to apply this 140 -year-old principle. In particular, which amount of $\mathrm{Fe}^{0}$ material? Which mixing ratio? Which bed length or how many columns? For which volume of clean water per unit time (day, hour)? Required experiments should last for long times (at least one year) as there is no way to reproduce accelerated iron corrosion. The authors have been advocating for the past decade that designing such filters will universally provide safe drinking water to low-income communities worldwide [82-84].

\section{Conclusions}

The modified EDTA test provides an accurate and reliable tool to assess the intrinsic reactivity of $\mathrm{Fe}^{0} \mathrm{SW}$. The experiment is accomplished within two days and needs only a UV/vis spectrophotometer. Results from the EDTA test are corroborated by the MB test and by water defluoridation. The combination of the three methods provides a facile way to demonstrate the nonlinear nature of the corrosion rate. In particular, the results unambiguously established that water defluoridation with conventional $\mathrm{Fe}^{0}$ materials would be a laborious task. The combination of the three methods 
appears to be a reliable way to discuss the suitability of $\mathrm{Fe}^{0}$ materials for various applications. Future works should reproduce these experiments for longer experimental duration to use their full capacity in facilitating suitable materials for site-specific applications. The named combination of the three methods is also regarded as a universal testing procedure to evaluate new $\mathrm{Fe}^{0}$ for environmental applications (quality control).

Author Contributions: B.H., A.I.N.-T., M.L., T.L., and C.N. contributed equally to manuscript compilation and revisions. All authors have read and agreed to the published version of the manuscript.

Funding: This research has received no funding.

Acknowledgments: The manuscript was improved by insightful comments of anonymous reviewers from Processes. We acknowledge support by the German Research Foundation and the Open Access Publication Funds of the Göttingen University.

Conflicts of Interest: The authors declare no conflict of interest.

\section{References}

1. Bischof, G. The Purification of Water: Embracing the Action of Spongy Iron on Impure Water; Bell and Bain: Glasgow, UK, 1873; 19p.

2. Bischof, G. On putrescent organic matter in potable water. Proc. R. Soc. Lond. 1877, 26, 258-261.

3. Bischof, G. On putrescent organic matter in potable water II. Proc. R. Soc. Lond. 1878, 27, 152-156.

4. Notter, J.L. The purification of water by filtration. Br. Med. J. 1878, 12, 556-557. [CrossRef]

5. Nichols, W.R. Water Supply, Considered Mainly from a Chemical and Sanitary Standpoint; John Wiley \& Sons: New York, NY, USA, 1883; 260p.

6. Anderson, W. On the purification of water by agitation with iron and by sand filtration. J. Soc. Arts 1886, 35, 29-38. [CrossRef]

7. Devonshire, E. The purification of water by means of metallic iron. J. Frankl. Inst. 1890, 129, 449-461. [CrossRef]

8. Antia, D.D.J. Sustainable zero-valent metal (ZVM) water treatment associated with diffusion, infiltration, abstraction and recirculation. Sustainability 2010, 2, 2988-3073. [CrossRef]

9. Baker, M. Sketch of the history of water treatment. Am. Water Works Assoc. 1934, 26, 902-938. [CrossRef]

10. Van Craenenbroeck, W. Easton \& Anderson and the water supply of Antwerp (Belgium). Ind. Archaeol. Rev. 1998, 20, 105-116.

11. Mwakabona, H.T.; Ndé-Tchoupé, A.I.; Njau, K.N.; Noubactep, C.; Wydra, K.D. Metallic iron for safe drinking water provision: Considering a lost knowledge. Water Res. 2017, 117, 127-142. [CrossRef]

12. Lufingo, M.; Ndé-Tchoupé, A.I.; Hu, R.; Njau, K.N.; Noubactep, C. A novel and facile method to characterize the suitability of metallic iron for water treatment. Water 2019, 11, 2465. [CrossRef]

13. Ndé-Tchoupé, A.I. Design and Construction of $\mathrm{Fe}^{0}$-Based Filters for Hhouseholds. Ph.D. Thesis, University of Douala, Douala, Cameroon, 2019. (In French).

14. Lufingo, M. Investigation of Metallic Iron for Water Defluoridation. Master's Thesis, Nelson Mandela African Institution of Science and Technology, Arusha, Tanzania, 2020.

15. Dannenberg, R.O.; Potter, G.M. Silver Recovery from Waste Photographic Solutions by Metallic Displacement; Report of Investigations 7117; BuMines: Washington, DC, USA, 1968; 22p.

16. Anderson, M.A. Fundamental Aspects of Selenium Removal by Harza Process; Rep San Joaquin Valley Drainage Program; US Dep Interior: Sacramento, CA, USA, 1989.

17. Martins, G.F. Percent oxygen in air. J. Chem. Educ. 1987, 64, 809. [CrossRef]

18. Gordon, J.; Chancey, K. Steel wool and oxygen: A look at kinetics. J. Chem. Educ. 2005, 82, 1065. [CrossRef]

19. Vogelezang, M. Steel wool and oxygen: How constant should a rate constant be? J. Chem. Educ. 2006, 83, 214. [CrossRef]

20. Vera, F.; Rivera, R.; Núñez, C. A simple experiment to measure the content of oxygen in the air using heated steel wool. J. Chem. Educ. 2011, 88, 1341-1342. [CrossRef]

21. Lauderdale, R.A.; Emmons, A.H. A method for decontaminating small volumes of radioactive water. J. Am. Water Works Assoc. 1951, 43, 327-331. [CrossRef] 
22. Lacy, W.J. Removal of radioactive material from water byslurrying with powdered metal. J. Am. Water Works Assoc. 1952, 44, 824-828. [CrossRef]

23. Sifrin, S.M.; Spivakova, O.M.; Krasnoborod'ko, I.G. On color removal from textile wastewater. Sel. Pap. Leningr. Civ. Eng. Inst. 1971, 69, 112-119.

24. Sugimoto, S.; Sakaki, T. Study on decontamination of radioactive ruthenium by steel wool in waste solution. Radioisotopes 1979, 28, 361-366. [CrossRef]

25. Tseng, C.L.; Yang, M.H.; Lin, C.C. Rapid determination of cobalt-60 in sea water with steel wool adsorption. J. Radioanal. Nucl. Chem. Lett. 1984, 85, 253-260. [CrossRef]

26. Albinsson, Y.; Christiansen-Saetmark, B.; Engkvist, I.; Johansson, W. Transport of actinides and Technetium through a bentonite backfill containing small quantities of iron or copper. Radiochim. Acta 1991, 52-53, 283.

27. Khudenko, B.M. Feasibility evaluation of a novel method for destruction of organics. Water Sci. Technol. 1991, 23, 1873-1881. [CrossRef]

28. Gould, J.P. The kinetics of hexavalent chromium reduction by metallic iron. Water Res. 1982, 16, 871-877. [CrossRef]

29. Erickson, A.J. Enhanced Sand Filtration for Storm Water Phosphorus Removal. Master's Thesis, University of Minnesota, Minneapolis, MN, USA, 2005.

30. Erickson, A.J.; Gulliver, J.S.; Weiss, P.T. Enhanced sand filtration for storm water phosphorus removal. J. Environ. Eng. 2007, 133, 485-497. [CrossRef]

31. Erickson, A.J.; Gulliver, J.S.; Weiss, P.T. Phosphate removal from agricultural tile drainage with iron enhanced sand. Water 2017, 9, 672. [CrossRef]

32. Del Cul, G.D.; Bostick, W.D.; Trotter, D.R.; Osborne, P.E. Technetium-99 removal from process solutions and contaminated groundwater. Sep. Sci. Technol. 1993, 28, 551-564. [CrossRef]

33. Del Cul, G.D.; Bostick, W.D. Simple method for technetium removal from aqueous solutions. Nucl. Tecknol. 1995, 101, 161. [CrossRef]

34. James, B.R.; Rabenhorst, M.C.; Frigon, G.A. Phosphorus sorption by peat and sand amended with iron oxides or steel wool. Water Environ. Res. 1992, 64, 699-705. [CrossRef]

35. Ndé-Tchoupé, A.I.; Crane, R.A.; Mwakabona, H.T.; Noubactep, C.; Njau, K.N. Technologies for decentralized fluoride removal: Testing metallic iron based filters. Water 2015, 7, 6750-6774. [CrossRef]

36. Campos, V. The effect of carbon steel-wool in removal of arsenic from drinking water. Environ. Geol. 2002, 42, 81-82. [CrossRef]

37. Cornejo, L.; Lienqueo, H.; Arenas, M.; Acarapi, J.; Contreras, D.; Yáñez, J.; Mansilla, H.D. In field arsenic removal from natural water by zero-valent iron assisted by solar radiation. Environ. Pollut. 2008, 156, 827-831. [CrossRef]

38. Özer, A.; Altundogan, H.S.; Erdem, M.; Tümen, F. A study on the $\mathrm{Cr}(\mathrm{VI})$ removal from aqueous solutions by steel wool. Environ. Pollut. 1997, 97, 107-112. [CrossRef]

39. Gromboni, C.F.; Donati, G.L.; Matos, W.O.; Neves, E.F.A.; Nogueira, A.R.A.; Nobrega, J.A. Evaluation of metabisulfite and a commercial steel wool for removing chromium (VI) from wastewater. Environ. Chem. Lett. 2010, 8, 73-77. [CrossRef]

40. Till, B.A.; Weathers, L.J.; Alvarez, P.J.J. Fe(0)-supported autotrophic denitrification. Environ. Sci. Technol. 1998, 32, 634-639. [CrossRef]

41. Lavania, A.; Bose, P. Effect of metallic iron concentration on end-product distribution during metallic iron-assisted autotrophic denitrification. J. Environ. Eng. 2006, 132, 994-1000. [CrossRef]

42. Bradley, I.; Straub, A.; Maraccini, P.; Markazi, S.; Nguyen, T.H. Iron oxide amended biosand filters for virus removal. Water Res. 2011, 45, 4501-4510. [CrossRef] [PubMed]

43. Tepong-Tsindé, R.; Ndé-Tchoupé, A.I.; Noubactep, C.; Nassi, A.; Ruppert, H. Characterizing a newly designed steel-wool-based household filter for safe drinking water provision: Hydraulic conductivity and efficiency for pathogen removal. Processes 2019, 7, 966. [CrossRef]

44. Li, Z.; Huang, D.; McDonald, L.M. Heterogeneous selenite reduction by zero valent iron steel wool. Water Sci. Technol. 2017, 75, 908-915. [CrossRef]

45. Hildebrant, B. Characterizing the reactivity of commercial steel wool for water treatment. Freib. Online Geosci. 2018, 53, 1-60.

46. Mitchell, G.; Poole, P.; Segrove, H.D. Adsorption of methylene blue by high-silica sands. Nature 1955, 176, 1025-1026. [CrossRef] 
47. Btatkeu-K, B.D.; Miyajima, K.; Noubactep, C.; Caré, S. Testing the suitability of metallic iron for environmental remediation: Discoloration of methylene blue in column studies. Chem. Eng. J. 2013, 215-216, 959-968.

48. Miyajima, K.; Noubactep, C. Impact of $\mathrm{Fe}^{0}$ amendment on methylene blue discoloration by sand columns. Chem. Eng. J. 2013, 217, 310-319. [CrossRef]

49. Miyajima, K. Optimizing the design of metallic iron filters for water treatment. Freib. Online Geosci. 2012, 32, $1-60$.

50. Reardon, J.E. Anaerobic corrosion of granular iron: Measurement and interpretation of hydrogen evolution rates. Environ. Sci. Technol. 1995, 29, 2936-2945. [CrossRef] [PubMed]

51. Reardon, E.J. Zerovalent irons: Styles of corrosion and inorganic control on hydrogen pressure buildup. Environ. Sci. Tchnol. 2005, 39, 7311-7317. [CrossRef] [PubMed]

52. Miehr, R.; Tratnyek, G.P.; Bandstra, Z.J.; Scherer, M.M.; Alowitz, J.M.; Bylaska, J.E. Diversity of contaminant reduction reactions by zerovalent iron: Role of the reductate. Environ. Sci. Technol. 2004, 38, 139-147. [CrossRef] [PubMed]

53. Kim, H.; Yang, H.; Kim, J. Standardization of the reducing power of zero-valent iron using iodine. J. Environ. Sci. Health A 2014, 49, 514-523. [CrossRef]

54. Li, S.; Ding, Y.; Wang, W.; Lei, H. A facile method for determining the $\mathrm{Fe}(0)$ content and reactivity of zero valent iron. Anal. Methods 2016, 8, 1239-1248. [CrossRef]

55. Li, J.; Dou, X.; Qin, H.; Sun, Y.; Yin, D.; Guan, X. Characterization methods of zerovalent iron for water treatment and remediation. Water Res. 2019, 148, 70-85. [CrossRef]

56. Miyajima, K.; Noubactep, C. Effects of mixing granular iron with sand on the efficiency of methylene blue discoloration. Chem. Eng. J. 2012, 200-202, 433-438.

57. Miyajima, K.; Noubactep, C. Characterizing the impact of sand addition on the efficiency of granular iron for water treatment. Chem. Eng. J. 2015, 262, 891-896. [CrossRef]

58. Naseri, E.; Ndé-Tchoupé, A.I.; Mwakabona, H.T.; Nanseu-Njiki, C.P.; Noubactep, C.; Njau, K.N.; Wydra, K.D. Making $\mathrm{Fe}^{0}$-Based filters a universal solution for safe drinking water provision. Sustainability 2017, 9, 1224. [CrossRef]

59. Phukan, M. Characterizing the $\mathrm{Fe}^{0}$ /sand system by the extent of dye discoloration. Freib. Online Geosci. 2015, 40, 1-70.

60. Varlikli, C.; Bekiari, V.; Kus, M.; Boduroglu, N.; Oner, I.; Lianos, P.; Lyberatos, G.; Icli, S. Adsorption of dyes on Sahara desert sand. J. Hazard. Mater. 2009, 170, 27-34. [CrossRef]

61. Saywell, L.G.; Cunningham, B.B. Determination of iron: Colorimetric o-phenanthroline method. Ind. Eng. Chem. Anal. Ed. 1937, 9, 67-69. [CrossRef]

62. Buck, R.P.; Rondinini, S.; Covington, A.K.; Baucke, F.G.K.; Brett, C.M.A.; Camoes, M.F.; Milton, M.J.T.; Mussini, T.; Naumann, R.; Pratt, K.W.; et al. Measurement of pH. Definition, standards, and procedures (IUPAC Recommendations 2002). Pure Appl. Chem. 2002, 74, 2169-2200. [CrossRef]

63. Noubactep, C.; Meinrath, G.; Dietrich, P.; Sauter, M.; Merkel, B. Testing the suitability of zerovalent iron materials for reactive Walls. Environ. Chem. 2005, 2, 71-76. [CrossRef]

64. Ibanez, J.G.; Gonzalez, I.; Cardenas, M.A. The effect of complex formation upon the redox potentials of metallic ions: Cyclic voltammetry experiments. J. Chem. Educ. 1998, 65, 173-175. [CrossRef]

65. Rizvi, M.A. Complexation modulated redox behavior of transition metal systems. Rus. J. Gen. Chem. 2015, 85, 959-973. [CrossRef]

66. Heimann, S. Testing granular iron for fluoride removal. Freib. Online Geosci. 2018, 52, 1-80.

67. Heimann, S.; Ndé-Tchoupé, A.I.; Hu, R.; Licha, T.; Noubactep, C. Investigating the suitability of $\mathrm{Fe}^{0}$ packed-beds for water defluoridation. Chemosphere 2018, 209, 578-587. [CrossRef]

68. Ndé-Tchoupé, A.I.; Nanseu-Njiki, C.P.; Hu, R.; Nassi, A.; Noubactep, C.; Licha, T. Characterizing the reactivity of metallic iron for water defluoridation in batch studies. Chemosphere 2019, 219, 855-863. [CrossRef]

69. Van Genuchten, C.M.; Behrends, T.; Stipp, S.L.S.; Dideriksen, K. Achieving arsenic concentrations of $<1 \mu \mathrm{g} / \mathrm{L}$ by $\mathrm{Fe}(0)$ electrolysis: The exceptional performance of magnetite. Water Res. 2020, 168, 115170.

70. Lavine, B.K.; Auslander, G.; Ritter, J. Polarographic studies of zero valent iron as a reductant for remediation of nitroaromatics in the environment. Microchem. J. 2001, 70, 69-83. [CrossRef]

71. Nesic, S. Key issues related to modelling of internal corrosion of oil and gas pipelines-A review. Corros. Sci. 2007, 49, 4308-4338. [CrossRef] 
72. Lazzari, L. General aspects of corrosion. In Encyclopedia of Hydrocarbons; Chapter 9.1; Istituto Enciclopedia Italiana: Rome, Italy, 2008; Volume V.

73. Moraci, N.; Lelo, D.; Bilardi, S.; Calabrò, P.S. Modelling long-term hydraulic conductivity behaviour of zero valent iron column tests for permeable reactive barrier design. Can. Geotech. J. 2016, 53, 946-961. [CrossRef]

74. Santisukkasaem, U.; Das, D.B. A non-dimensional analysis of permeability loss in zero-valent iron permeable reactive barrier (PRB). Transp. Porous Media 2019, 126, 139-159. [CrossRef]

75. Magomnang, A.A.S.; Villanueva, E.P. Removal of hydrogen sulfide from biogas using dry desulfurization systems. In Proceedings of the International Conference on Agricultural, Environmental and Biological Sciences (AEBS-2014), Phuket, Thailand, 24-25 April 2014; pp. 77-80.

76. Magomnang, A.; Villanueva, E.P. Utilization of the uncoated steel wool for the removal of hydrogen sulfide from biogas. Int. J. Min. Metall. Mech. Eng. 2015, 3, 108-111.

77. Riyadi, U.; Kristanto, G.A.; Priadi, C.R. Utilization of steel wool as removal media of hydrogen sulfide in biogas. IOP Conf. Ser. Earth Environ. Sci. 2018, 105, 012026. [CrossRef]

78. Noubactep, $\mathrm{C}$. The fundamental mechanism of aqueous contaminant removal by metallic iron. Water $S A$ 2010, 36, 663-670. [CrossRef]

79. Gheju, M. Hexavalent chromium reduction with zero-valent iron (ZVI) in aquatic systems. Water Air Soil Pollut. 2011, 222, 103-148. [CrossRef]

80. Ghauch, A. Iron-based metallic systems: An excellent choice for sustainable water treatment. Freib. Online Geosci. 2015, 32, 1-80.

81. Westerhoff, P.; James, J. Nitrate removal in zero-valent iron packed columns. Water Res. 2003, 37, 1818-1830. [CrossRef]

82. Noubactep, C.; Schöner, A.; Woafo, P. Metallic iron filters for universal access to safe drinking water. Clean Soil Air Water 2009, 37, 930-937. [CrossRef]

83. Nanseu-Njiki, C.P.; Gwenzi, W.; Pengou, M.; Rahman, M.A.; Noubactep, C. $\mathrm{Fe}^{0} / \mathrm{H}_{2} \mathrm{O}$ filtration systems for decentralized safe drinking water: Where to from here? Water 2019, 11, 429. [CrossRef]

84. Hu, R.; Yang, H.; Tao, R.; Cui, X.; Xiao, M.; Konadu-Amoah, B.; Cao, V.; Lufingo, M.; Soppa-Sangue, N.P.; Ndé-Tchoupé, A.I.; et al. Metallic Iron for Environmental Remediation: Starting an Overdue Progress in knowledge. Water 2020, in press.

(C) 2020 by the authors. Licensee MDPI, Basel, Switzerland. This article is an open access article distributed under the terms and conditions of the Creative Commons Attribution (CC BY) license (http://creativecommons.org/licenses/by/4.0/). 